\title{
A Comparison of Educational Reform in Finland and Washington State, USA
}

\begin{abstract}
Summary: This paper addresses aspects of global educational reform initiatives in the first two decades of the $21^{\text {st }}$ century, comparing and contrasting these with the efforts of Finland, a nation in which students have recently and repeatedly outperformed other countries on international assessments. Utilizing the thesis that lessons from Finland can be used to support the educational reform work in the United States, a proposal for such implementation in Washington state is presented. Since strategies are often contextual, rooted in the history, beliefs, politics, and more of a country, such implementation must necessarily include sound analysis and adaptations to suit the new circumstances. While this paper focuses on educational efforts, an analysis of the Programme for International Student Assessment (PISA) and Trends in Mathematics and Science Study (TIMSS) data by poverty identifies an important factor outside education that impacts academic achievement, namely, childhood poverty. The paper concludes with a practical look at possible next steps to improve education within the current educational context.
\end{abstract}

Keywords: educational reform, comparison Finnland and Washington State (USA), international academic achievements, effective school improvement

Zusammenfassung (Ein Vergleich der Bildungsreform in Finnland und Washington State, USA): Dieser Beitrag befasst sich mit Aspekten der globalen Bildungsreforminitiativen in den ersten beiden Jahrzehnten des 21. Jahrhunderts; er vergleicht und kontrastiert die Bemühungen von Finnland, einem Land, in dem die Schüler vor kurzem und immer wieder andere Länder in internationalen Leistungsbewertungen übertroffen haben. Unter Verwendung der These, dass die Lehren aus Finnland verwendet werden können, um die Bildungsreformarbeit in den Vereinigten Staaten zu unterstützen, wird ein Vorschlag für eine entsprechende Umsetzung im Staat Washington vorgestellt. Strategien sind oft kontextuell, historisch und durch Überzeugungen begründet, deshalb muss die Politik eines Landes eine solche Umsetzung notwendigerweise Stimmungsanalysen und Anpassungen einbeziehen und an die neuen Gegebenheiten anpassen. Während sich dieses Papier auf pädagogische Bemühungen konzentriert, zeigt eine Analyse der Programme for International Student Assessment (PISA) und Trends in Mathematics and Science Study (TIMSS) Daten, dass Armut, vor allem Kinderarmut, ein wichtiger Faktor außerhalb der Bildungseinrichtungen mit Auswirkungen auf akademische Leistung ist. Der Artikel schließt mit einem praktischen Blick auf mögliche nächste Schritte zur Verbesserung Bildung innerhalb des aktuellen pädagogischen Kontextes.

Schlüsselwörter: Bildungsreform, Vergleich Finnland and Washington State (USA), internationaler Schulleistungsvergleich, effektive schulische Reformen

Резюме: (Карин Маннс: Сравнение реформ образования в Финляндии и штате Вашингтон, США): данная статья занимается аспектами глобальных инициатив в области образования в первые два десятилетия 21-го века; она сравнивает и контрастирует усилия Финляндии, страны, в которой ученики постоянно превосходят учеников других стран в международных конкурсах. При использовании тезиса о том, что опыт Финляндии может быть использован при поддержке в проведении реформ образования в Соединенных Штатах, выдвигается предложение для соответствующей реализации реформ в штате Вашингтон. Стратегии часто являются контекстуальными, обоснованы исторически и на основании убеждений, поэтому политика страны 
должна при подобном изменении включать по необходимости анализ настроений и адаптацию и приводить в соответствие с новыми данностями. Концентрируясь на педагогических усилиях, данная статья показывает анализ Международной программы по оценке образовательных достижений учащихся (PISA) и Международного мониторингового исследования качества школьного математического и естественнонаучного образования (TIMSS) с данными о том, что бедность, прежде всего, детская бедность, является важным фактором за пределами учреждений образования с влиянием на академические успехи. Статья заканчивается практическим взглядом на возможные последующие шаги для улучшения образования внутри современного педагогического контекста.

Ключевые слова: реформы образования, сравнение Финляндии и штата Вашингтон (США), международные тесты знаний, эффективная школьная реформа

\section{Introduction}

As nations throughout our world recognize that a strong economy and national well-being require an effective educational system, "education development policies and reform strategies globally have intended to improve the quality of education, especially raising student achievement" (Sahlberg, 2007, p. 150). As Pasi Sahlberg explains, at least three common trends have been utilized globally. The first is standardization of education, which includes educational outcomes, centrally prescribed curriculum, and high stakes accountability. The second is an increased focus on literacy and numeracy, with schools reducing time in subjects other than reading, writing, and science, as a consequence of increased attention to international assessments. Sahlberg labels this policy approach as an emphasis on the "systemworld" of knowledge, rather than the "lifeworld" of culture - especially beliefs, values, morality, meaning and social experiences (Sahlberg, 2007, p. 151). The third trend is "the introduction of consequential accountability systems for schools. School performance - especially raising student achievement - is closely tied to processes of accrediting, promoting, inspecting, and, ultimately, rewarding or punishing schools and teachers" (Sahlberg, 2007, p. 151). These accountability systems focus on limited aspects of the educational process, such as standardized tests or observations of specific behaviors in the classroom.

In contrast, Finland has charted a course that provides a different approach. Education policies in Finland include flexibility and loose standards interpreted at the local level, broad learning combined with development of personality, morals, and creativity, and intelligent accountability with trust-based professionalism, which is an internal development of professional judgment cultivated in a context of trust (Sahlberg, 2007).

This paper uses an analysis of the policies and practices in Finland in a number of key areas identified by global scholars to develop a proposal for educational reform with the potential to impact student learning positively in our local context, the state of Washington. Specifically, the following areas will be addressed in the proposal: Approaches to educational reform, learning goals, centralization and decentralization, teacher quality, roles of the teacher, principal, and superintendent, family relations, pedagogy or role of the student, and other factors that lead to student success.

This proposal provides a comparison of aspects of Finland's successes with current practice and recommendations for the United States, and more specifically, Washington state. In doing so, potential change is analyzed with respect to feasibility of implementation, in the short-term or within a longer time frame. The presentation of the proposal concludes with a reflective synthesis of next steps. 


\section{Proposal}

As with any study of the educational system in other nations for the purposes of considering application of ideas to our own, it is imperative to begin with a reminder that successful practice is based not only upon the practices themselves, but also upon the context of the reforms, including the history, beliefs, political and economic systems, and more. For the purposes of this proposal, the practices recommended for consideration for implementation in the state of Washington are those that have been identified as factors impacting success in Finland and that would fit into current approaches in a complementary or at least feasible manner.

Presently the state of Washington, through the Office of the Superintendent of Public Instruction (OSPI), is developing a work plan for implementing new federal legislation, namely the Every Student Succeeds Act (ESSA). Following the lead of Finland, it would make sense to consider moving forward with this reform in a way that permits flexibility and decentralization, a broader perspective on learning, and "intelligent accountability" (Sahlberg, 2007). While the ESSA work is yet to be completed and a new superintendent for the state will be elected in November, it may be too soon to know whether this approach will be possible, although current conditions bode well.

In conversations with the one of the leaders at OSPI, she has provided permission for a region within the state and districts within that region to initiate practice that leaders within that locality deem best for students. She promises increasing flexibility with a posture from the State that leaders will "learn from the field" to identify policies and practices that result in increased learning.

Likewise, the proposal to include additional goals in the educational programs, those focused on character, citizenship, creativity, and collaboration among others, has been well-received, with the explicit discussion of the need for school leaders to attend to the moral purpose of schools, in addition to preparing students for career- and college-readiness. From this perspective, the possibility for regions within the state of Washington to serve as models for others in implementing broader educational goals exists.

However, in contrast to Washington's system of high-stakes standardized testing as a component of federal regulations and requirement for federal funding, Finland's national curriculum goals are not monitored by a national or regional system of inspectorate. As Sahlberg (2007) describes, this intelligent accountability permits student assessment to occur close to the student and system evaluation to occur locally, in ways determined by local practitioners. Mika Risku, Pekka Kanervio, and Lars Björk (2014) describe the shifting role of the superintendent, as she or he assumes responsibility for developing the platform for such system evaluation and guides the collection and analysis to make system improvements.

In response to concerns about the impact of testing on students, OSPI is now collecting data on the amount of time that children spend testing, an indication of initial awareness of impact of this global trend, although albeit, very limited at this time. Due to these constraints, intelligent accountability, the third element of Finnish reform as articulated by Sahlberg (2007), must proceed within the context of a pervasive culture of high-stakes assessment in Washington for now. 
One of the factors that lead to effective school improvement, as studied by Hechuan Sun, Bert Creemers, and Rob de Jong (2006), is national goal setting. Finland's national goals and objectives are clearly articulated, although, as discussed later, the implementation and accountability for these goals is delegated to the local level. In comparison, Washington now also has "Washington State Learning Standards" in place, which effectively are identical to the Common Core State Standards and Next Generation Science Standards, guiding college- and career-readiness for grades K-12. Similarity between Washington's goals and those of other states allow for joint development of materials and practices.

Sun, Creemers, and de Jong (2006) also explore the concept of centralization and decentralization with regard to effective school improvement (ESI), noting that "centralization or decentralization is not the decisive factor for ESI. It depends more upon what should be centralized and what should be decentralized, according to a nation's context. To be more precise, ESI requires functional centralization or functional decentralization" (p. 114). As Sahlberg (2007) describes, education policies in Finland utilize both flexibility and loose standards, "Building on existing good practices and innovations in school-based curriculum development, setting of learning targets and networking through steering by information and support."

In Washington State, many aspects of the educational reform work has been structured in a centralized fashion by the federal government. With the transition to ESSA and the emerging support for decisionmaking at the local level, windows of opportunity are opening for identification of aspects of decentralization that can lead to increased student learning. Given that ESSA will look different from state to state and that in Washington, some guidelines will emerge from the state level with a concurrent attitude of 'learning from the field,' the proposal for a well-informed, research-based approach to centralization and decentralization that fits the current state context is likely premature.

Finland ensures that its students learn from high-quality teachers. As described by Olli-Pekka Maninine, Pertti Väisänen, and Hannu Savolainen (2012), entrance to the education programs are very competitive and rigorous, including a test of aptitude, and since 1979, basic qualifications for both primary and secondary teachers include a master's degree. In comparison, Dan Goldhaber and Joe Walch (2014) describe the increase in teacher qualification over the years in the United States, noting however that teaching candidates continue to be drawn from the lower end of the performance curve.

While it would be worthwhile to consider raising the qualifications for teacher candidates as a component of this proposal for increasing student learning in Washington schools, this action would most likely result in short-term challenges, such as a lack of teachers to fill classrooms, already a looming issue for many districts. This aspect of an effective system in Finland also rests upon some conditions currently not present in United States schools, including the high respect for the teaching profession and commensurate pay. As a long-term strategy, increasing the quality of teachers should be considered as an option to explore more fully.

However, given that it is unlikely that the quality of incoming educators can be increased within the near future, the aspect of teacher preparation and ongoing teacher development in Finland deserve consideration. Teacher preparation in Finland includes several important components, founded on a research base and including teacher pedagogical practices, subject learning, and a breadth of other studies that encompass the arts and physical fitness (Malinen, Väisänen, \& Savolainen, 2012). Teachers participate in four practice courses, three of which take place in university schools, with extensive use of reflective 
practice, including learning logs and portfolios, with regular feedback from instructors. The focus of the teacher preparation programs is to develop teachers that approach their work with a research-oriented perspective.

Teacher education varies among institutions in Washington, with assessments and required tasks providing more uniformity over time. Given the success of a research-oriented stance to teacher preparation and teacher development, this proposal includes a recommendation to infuse professional learning at levels with an inquiry perspective grounded in research. Currently, many districts are already reenvisioning professional learning through a 'cycle of inquiry' approach, so it makes sense to articulate this work more clearly at the individual teacher level. Were professional learning communities to function in ways similar to the interaction between professionals in Finnish schools, they might also be more likely to lead to increases in teacher effectiveness, innovation, and over time, student achievement.

Mika Risku, Lars Björk, and Tricia Browne-Ferrigno (2012) describe engagement of families in Finnish schools, as the parents and guardians participate actively in decision-making about student goals, curriculum, assessments, and more. Principals are charged with ensuring that families are welcomed fully and can easily access opportunities for involvement. Principals also ensure that their staffs have the knowledge and skills that they need to interact effectively with families.

This recommendation is already an integral component in many of OSPI's program requirements, including Title I, Learning Assistance Program, and programs serving English Language Learners. While strategies are shared to and among districts, many schools still struggle in creating authentic family engagement. Since principals are already faced with many challenges as instructional and managerial leaders, this proposal encourages school systems to develop supports for principals in forging these home-school connections and in providing guidance for teachers as they move forward in this direction.

The Finnish superintendent's role has necessarily changed over the past years due to economic forces and changes in governance. Current United States Interstate School Leadership Licensure Consortium (ISLLC) standards that guide certification and evaluation of superintendents include many aspects of the role of superintendent in Finland. While the Finnish superintendent plays an active part as a statesman, navigates the political landscape, and serves as contributing member of the regional executive team (Risku, Kanervio, Björk, 2014), this proposal recommends that superintendents take a more active role under ISLLC Standard 6, which requires that the superintendent be an educational leader who promotes the success of all students by understanding, responding to, and influencing the larger political, social, economic, legal, and cultural context by shaping legislation that will impact education. While many superintendents already do so, this shift from an education agenda shaped by legislators, by one defined and informed by educational leaders, holds promise.

Teachers in Finland understand that the educational system is shifting to provide meaningful learning for students, wherein students are active participants in developing their understanding (Ahonen, Pyhältö, Pietarinen, \& Soini, 2013). However, Finnish teachers have varied beliefs about their roles and those of their students, which the researchers note can be problematic when the teachers seek to learn more about how to facilitate conceptual change for students. It is challenging to learn new ways of performing when internal schema and beliefs are not structured in such a way as to accept this new knowledge. In other words, the authors imply that teachers would need to do their own cognitive restructuring in order to develop deep understanding of new pedagogical practices. 
In Washington schools, our new instructional models and new standards point to the need for constructivist approaches in supporting students in developing conceptual understanding through student talk and active engagement with learning. However, as illuminated by the research conducted by Elsi Ahonen, Kirsi Pyhälto, Janne Pietarinen, and Tiina Soini (2013), unless teachers are supported in changing their own conceptual schema, it is challenging for them to make the changes necessary. This proposal includes the recommendation that professional learning for staff model and guide participants through a constructivist approach that allows them to experience meaningful learning, while supporting their own shifts in schema so as to be able to connect new learning and subsequent experiences. The process of reflective practice that Olli-Pekka Malinen, Pertti Väisänen, and Hannu Savolainen (2012) describe as part of new teacher preparation can support educators in making these cognitive shifts that will support a change in practice.

O. Samdal, B. Wold, and M. Bronis (2010) identify that students' satisfaction with school, their perception of teacher expectations, and relationships with peers correlate strongly with student achievement. In Washington, a push for academic success as a reaction to increased accountability has caused teachers and families to yearn for the connections remembered from earlier times. This proposal urges educators collectively to develop a classroom and school culture that focuses not only on academic achievement, as defined in the Association of Washington School Principals (AWSP) evaluation rubrics, but that also nurtures the "whole child," providing intellectual, emotional, and physical safety as children are guided in their growth.

Another finding from Finland, and other European nations, is that school systems are much more effective when management and labor work collaboratively (Tucker, 2012). Such collaboration overcomes the impediments of selection by seniority and preservation of unsatisfactory employees. However, contrary to the approach of leaders in the United States who would seek to abolish unions, the approach in Finland empowered union leaders with an authentic seat at the table in a context of trust.

This proposal seeks to continue first steps in some of the districts in Washington State. As trust is generated and power shared, union leaders recognize roadblocks and are willing to engage in writing memorandums of agreement to facilitate decision-making that is most conducive to student learning. This proposal presupposes a willingness on the part of educational leaders to generate a context of trust and a professionalism of the teaching environment. Naturally, not all union leaders are willing to move in this direction, but this proposal encourages educational leaders to begin the process.

Recognizing the benefit of innovation in finding solutions to issues as they emerge, Scott Ellison (2009) studied the effects of two approaches to innovation, a competitive marketplace approach, often touted in the United States and implemented through charter schools and vouchers, and the Finnish approach, which includes cultivating an environment of creativity and risk-taking. Ellison found that marketplace innovations did not lead to increased student achievement, but only to an improvement in marketing materials. In contrast, the Finnish approach is grounded on the "teacher as researcher" model described earlier, in which the teacher functions autonomously to make research-based decisions about teaching methods and materials.

Ellison writes that within a context of decentralizations, a strong educational system includes "continuous professional development, collaboration, mentoring, and training programs throughout the system", and he adds: "an innovative education sector must be built upon the foundation of professional teaching 
and administration" (Ellison, 2009, p. 44). This proposal recommends, as previously stated, that educational leaders foster a professional and trusting culture, in which teachers' abilities to make effective decisions for their students are encouraged and nurtured within a system that provides ample support through ongoing learning opportunities. For students' needs to be met well, teachers must be supported in implementing innovative and reflective practice.

The recommendations in this proposal are all education-specific, but would not be complete without the insight from Christopher Tienken (2013), academic editor of the Kappa Delta Pi Record, who analyzed results of the PISA and TIMSS with regard to poverty levels. When comparing national performance by poverty level, the United States rises to a much higher level on both tests, leading the author to conclude that childhood poverty plays an influential role in the academic attainment of students. Given this finding, he urges educational leaders to address this issue whenever recommending other educational reforms to be implemented.

\section{Conclusion}

While every nation's unique context shapes educational policies and practices, the lessons from Finland can help prompt reflective conversation about our own educational system. As such, the proposal presented in this paper highlights findings that could be initiated or further developed in the educational systems currently at work in Washington state.

In distilling the recommendations within this proposal, practical next steps emerge. Recognizing a climate increasingly receptive to some degree of decentralization and a broader definition of education should be capitalized upon in the most effective manner, so as to leverage the opportunity presently provided by OSPI. Internally, efforts toward 'intelligent accountability' can pave the way for possible future shifts. Of high importance is creating cultures of trust and risk-taking, with ample support for ongoing learning designed to model and engage adult learners in research-based experiences that lead to meaningful learning. Such learning can result in shifts in practice, by which teachers increasingly assume the role of professional educator, utilizing a research base to make decisions about lesson design and materials that will best serve their students. Through these actions, the teaching profession becomes more professional, which implicitly raises expectations and builds a foundation for meeting students' needs through innovation and collaboration among all players, including administrators, teachers, family, and community. This work calls for a renewed commitment to educating the 'whole child,' with a strategic and long-term perspective that prepares our students for an unknown future.

As Finland and the United States continue efforts to lead educational reform that impacts student learning, ongoing research about progress in both countries will be beneficial. In particular, further study of the effects of centralization and decentralization, professional development for teachers, the teacher as a research-based professional, and the role of innovation will be useful. Likewise, investigation of noneducational factors that influence academic achievement, such as childhood poverty, is warranted. To ensure that education fully prepares students for the future, continued discussion regarding the breadth of education, including development of character, citizenship, critical thinking, collaboration, and more will be important. 


\section{References}

Ahonen, Elsi; Pyhältö, Kirsi; Pieterinen, Janne \& Soini, Tiina (2014): Teachers' professional beliefs about their roles and the pupils' roles in the school. In: Teacher Development: An international journal of teachers' professional development, Vol. 18, No. 2, pp. 177-197.

Ellison, Scott (2009): Hard-wired for innovation? Comparing two policy paths toward innovative schooling. In: International Education, Fall 2009, pp. 30-48.

Goldhaber, Dan \& Walch, Joe (2014): Gains in teacher quality. In: EducationNext, Vol. 14, No. 1 [ [http://educationnext.org/gains-in-teacher-quality/ (retrieved: July 15, 2016)].

Malinen, Olli-Pekka; Väisänen, Pertti \& Savolainen, Hannu (2012): Teacher preparation in Finland: A review of a national effort for preparing teachers for the future. In: The Curriculum Journal, Vol, 23, No. 4, pp. 567-584.

Risku, Mika; Björk, Lars; Browne-Ferrigno, Tricia (2012): School-parent relations in Finland. In: Journal of School Public Relations, Vol, 33, pp. 48-71.

Risku, Mika; Kanervio, Pekka; \& Björk, Lars (2014): Finnish Superintendents: Leading in a changing education policy context. In: Leadership and Policy in Schools, Vol. 13, pp. 383-406.

Sahlberg, Pasi (2007): Education policies for raising student learning: The Finnish approach. In: Journal of Education Policy, Vol. 22, No. 2, pp. 147-171.

Samdal, O. Wold, B. \& Bronis, M (2009): Relationship between students' perceptions of school environment, their satisfaction with school and perceived academic achievement: An international study. In: School Effectiveness and School Improvement, Vol. 10, No. 3, pp. 296-320.

Sun, Hechuan; Creemers, Bert; deJong, Rob (2005): Contextual factors and effective school improvement. In: School Effectiveness and School Improvement, Vol, 18, No. 1, pp. 93-122.

Tienken, Christopher (2013): For the record. In: Kappa Delta Pi Record, Vol. 49, pp. 56-58.

Tucker, Marc (2012): A different role for teachers unions? In: EducationNext, Vol.12, No. 1 [http://educationnext.org/a-different-role-for-teachers-unions/ (retrieved: July 12, 2016)].

\section{About the Author}

Karin Manns: Director of Curriculum and Instruction in the Granite Falls School District, Washington State; doctoral student at Seattle Pacific University, Washington State, USA; contact: mannsb@spu.edu 